\title{
Development and validation of the Family Vulnerability Index to Disability and Dependence (FVI-DD)
}

\author{
DESENVOLVIMENTO E VALIDAÇÃO DO ÍNDICE DE VULNERABILIDADE DE FAMÍLIAS A \\ INCAPACIDADES E DEPENDÊNCIA (IVF-ID)
}

\author{
DESARROLLO Y VALIDACIÓN DEL INDICE DE VULNERABILIDAD DE LAS FAMILIAS A \\ DISCAPACIDAD Y DEPENDENCIA (IVF-ID)
}

\section{Fernanda Amendola ${ }^{1}$, Márcia Regina Martins Alvarenga ${ }^{2}$, Maria do Rosário Dias de Oliveira Latorre $^{3}$, Maria Amélia de Campos Oliveira ${ }^{4}$}

\begin{abstract}
This exploratory, descriptive, cross-sectional, and quantitative study aimed to develop and validate an index of family vulnerability to disability and dependence (FVI-DD). This study was adapted from the Family Development Index, with the addition of social and health indicators of disability and dependence. The instrument was applied to 248 families in the city of Sao Paulo, followed by exploratory factor analysis. Factor validation was performed using the concurrent and discriminant validity of the Lawton scale and Katz Index. The descriptive level adopted for the study was $p<0.05$. The final vulnerability index comprised 50 questions classified into seven factors contemplating social and health dimensions, and this index exhibited good internal consistency (Cronbach's alpha $=0.82)$. FVI-DD was validated using both the Lawton scale and Katz Index. We conclude that FVI-DD can accurately and reliably assess family vulnerability to disability and dependence.
\end{abstract}

\section{DESCRIPTORS}

Family

Family Health Program

Indicators

Health vulnerability

Validation studies

\section{RESUMO}

Pesquisa exploratória, descritiva, transversal, de abordagem quantitativa, cujo objetivo foi desenvolver e validar um índice de vulnerabilidade de famílias a incapacidades e dependência (IVF-ID). Adaptou-se o Índice de Desenvolvimento da Família (IDF), acrescentando indicadores de relações sociais e de saúde relacionados a incapacidades e dependência. Aplicou-se o instrumento a 248 famílias de uma região do município de São Paulo e realizou-se a análise fatorial exploratória. A validação dos fatores foi feita por meio das validades discriminante e concorrente, utilizando a escala de Lawton e o índice de Katz. O nível descritivo adotado para o estudo foi $p<0,05$. $O$ Índice final resultou em 50 questões, divididas em sete fatores, englobados em dimensões sociais e de saúde, com boa consistência interna (alfa de Cronbach=0,82). O IVF-ID foi validado para ambas as escalas. Conclui-se que o IVF-ID mostrou-se confiável e válido para identificar a vulnerabilidade de famílias para incapacidades e dependência

\section{DESCRITORES \\ Família \\ Programa Saúde da Família \\ Indicadores \\ Vulnerabilidade em saúde \\ Estudos de validação}

\begin{abstract}
RESUMEN
Investigación cuantitativa, exploratoria, descriptiva y transversal, con objetivo de desarrollar y validar un índice de vulnerabilidad de la familia a la discapacidad y la dependencia (IVF-ID). El Índice de Desarrollo de la Familia (IDF) fue adaptado, añadiendo indicadores de relaciones sociales e de salud relacionados a discapacidad y dependencia. Se aplicó el instrumento a 248 familias de una región de São Paulo y ae realizó un análisis factorial exploratoria. La validación fue hecha a través de la validez discriminante y la validez concurrente, con la utilización de las escalas de Lawton y Katz. Se adoptó el nivel descriptivo de $p<0,05$. El índice final resultó en 50 preguntas divididas en siete factores, incluidos en las dimensiones sociales y de salud, con buena consistencia interna (alfa de Cronbach=0,82). EI IVF-ID fue validado para ambas escalas. Se concluí que el IVFID es fiable y válido para identificar la vulnerabilidad de las familias a la discapacidad y la dependencia.
\end{abstract}

\section{DESCRIPTORES}

Familia

Programa de Salud de la Familia

Indicadores

Vulnerabilidad en salud

Estudios de validación 


\section{INTRODUCTION}

Chronic health conditions tend to increase with the prevalence of chronic diseases associated with demographic, economic, and lifestyle changes. As a consequence, the number of people with disabilities and dependence also tends to increase. In Brazil, these changes occurred in a few decades, and the social and health programs and policies created to meet the increasing health demands are still in their infancy.

Homecare services provided to people with disabilities and dependence have been expanding in Brazil ${ }^{(1)}$. These services must be integrated into the routine of primary care professionals who, in turn, need to be prepared to assist them. The early detection of vulnerabilities is equally important and requires adequate tools to help health professionals identify and intervene in situations of vulnerability, particularly those involving the prevention and reduction of harm.

Several social and health conditions can amplify stress conditions in families and lead to disability and dependence. Disability is a generic term that includes impairments and limitations in activities of daily living (ADL) and in social perspectives $^{(2)}$. On the other hand, dependence indicates difficulties or the inability to perform basic or essential ADL without aid. In both cases, families become more vulnerable.

The identification of families at an increased vulnerability risk may enable the planning of actions to monitor living and health conditions and to create appropriate interventions. In view of these vulnerabilities, the risk of exposure to adverse situations arises not only from individual factors but also from social aspects that may result in increased susceptibility and potentially limit the availability of and access to protective resources ${ }^{(3)}$.

Family conditions such as the presence of elderly or chronic diseases are strongly associated with the appearance of disability and dependence ${ }^{(4)}$. On the other hand, the association of vulnerability with social conditions is not easily perceptible, although previous studies have indicated a direct association between sociodemographic aspects and functional capacity ${ }^{(5-7)}$.

Therefore, the aim of this study was to develop and validate a family vulnerability index to disability and dependence (FVI-DD) using data from families that were accompanied by family health professionals in distinct neighborhoods in the city of Sao Paulo for better assessing the vulnerability to disability and dependence and for using this index to better evaluate primary health care for these families.

\section{METHOD}

This exploratory, descriptive, cross-sectional, and quantitative study used a sample population comprising families that were served by family health professionals in the city of Sao Paulo. This study focused on families living in the neighborhood of Lapa, which was selected for developing the index because of its demographic characteristics, i.e., the proportion of elderly ( $\geq 60$ years) is the highest in the city (16.5\%) and the rate of aging (110.1\%) is higher than the overall rate in the city of Sao Paulo (57.3\%)(8). In 2011, the neighborhood of Lapa had three Family Health Units (FHU), where the present study was conducted.

Families eligible to enroll in this study needed to be registered in FHU and were required to have a family member in the household at the time of the interview. Registered participants who did not live in the household, e.g., domestic servants, were excluded from the study.

The study was approved by the Ethics Committee of the School of Nursing (N. 960/2010-CEP/EEUSP) and by the Municipal Health Secretariat of Sao Paulo (N. 410/10CEP/SMS). Participants were informed about the objectives of the research and about data confidentiality in accordance with National Council of Ethics Resolution 196/96, and they also signed a consent form.

Based on a vulnerability prevalence of $30 \%$, a standard error of $\pm 10 \%, \alpha$ of $5 \%$, and power of $80 \%$, it was estimated that 138 families would be necessary to meet the proposed objectives. Because of eventual losses, the sample size was doubled, totaling 276 randomly selected families. To select families to participate in the draw, the databases from the Primary Care Information System were consulted. Lots were systematically drawn to select the registered families and order the draw list according to the Family Health team number, code number of each neighborhood, and the number of people in each household.

The Family Development Index proposed by Carvalho, Barros, and $\mathrm{Franco}^{(9)}$ was used to develop FVI-DD. The steps for the index development and validity have been described in a previous publication ${ }^{(10)}$. After validation of the index by a panel of assessors, FVI-DD comprised 103 questions, which were classified into eight distinct dimensions.

In the proposed instrument, all questions related to the presence of certain conditions in the family. A household member capable of responding on behalf of the family answered each question. All questions were close and therefore the respondents' answers were either YES or NO. For some questions, affirmative responses indicated the presence of vulnerability and were assigned a score of 1 , whereas negative responses indicated the absence of vulnerability and were assigned a score of 0 . For other questions, the assignment of scores was inverted.

To select the questions for the final FVI-DD, exploratory factor analysis was conducted. This analysis was performed using Kaiser-Meyer-Olkin (KMO) measure of $>1$ and orthogonal varimax rotation and correlation coef- 
ficient of $>0.40$. The scores were calculated on the basis of the sum of the responses defined for each factor. In addition, Cronbach's $\alpha$-coefficient was used for internal consistency analysis of each score.

The profiling of family members was performed by descriptive statistics, including number and percentage, mean, standard deviation, median, and minimum and maximum. The Kolmogorov-Smirnov test was used to assess adherence to the normal distribution of quantitative variables. Nonparametric tests were used because several variables did not exhibit a normal distribution. The validation of factors in relation to dependence was performed using the discriminant and concurrent validity of both the Lawton scale and Katz Index ${ }^{(11)}$.

To assess the independence in basic ADL (BADL), the Katz Index ${ }^{(11)}$ was used, which determines independence levels in the performance of six basic and integrated functions: bathing, dressing, using the bathroom, transferring, continence, and feeding. To assess the independence in instrumental ADL (IADL), the Lawton scale was used, which explores a more complex level of functionality and describes activities that are essential for environmental adaptation, particularly community activities, which are more cognitively influenced. The index version used was the one recommended by the Ministry of Health in the Primary Care Guideline No. 19 - Health of the Elderly ${ }^{(12)}-$ that classifies people's independence on the basis of the performance of 9 functions.

For discriminant validity analysis, the means of the FVI-DD factors were determined by comparing households with and without dependence. The families considered dependent exhibited a classification score on the Katz Index, except the letter A (independence in all activities) and a score of less than 27 on the Lawton scale. The Mann-Whitney test was also used in this analysis. For concurrent validity analysis, Spearman's correlation coefficient was calculated between the indicators and the scores on the Katz Index and Lawton scale.

With regard to FVI-DD, the higher the score, the greater the vulnerability to disability and dependence. However, cutoffs were used to classify family vulnerability. For this purpose, a receiver operating characteristic (ROC) curve was constructed according to the Lawton scale. The descriptive level adopted for this study was $p<0.05$. Data analysis was performed using version 15.0 of Statistical Package for Social Sciences software.

\section{RESULTS}

\section{Profile of the interviewed families}

The number of families interviewed was homogeneous in each of the three FHU, being exactly the same in the neighborhoods of Parque da Lapa and Vila Jaguara (78) and higher in FHU located in the neighborhood of
Vila Piauí (92), totaling 248 households, which was above the estimated number of families (138). The average number of people per household was 3.2. Approximately $56 \%$ of families had between two and three members, and $16.1 \%$ of them had up to four members. Of note, the number of people living alone represented $9.7 \%$ of the total sample. In addition, there was a predominance of women (54.6\%) and adults aged $18-59$ years (54.0\%), and a similar percentage of children, teenagers, and young people (23.2\%) compared to the elderly (22.8\%). The mean age was $39.1 \pm 23.9$ years, and the maximum age was 93 years.

Over $90.0 \%$ of the families were completely independent: $97.0 \%$ using the Katz Index and $92.2 \%$ using the Lawton scale. Only $9.3 \%$ of the interviewed families had at least one member with partial or complete dependence in one or more BADL. Approximately one fourth of the sample $(22.2 \%)$ had partial or complete dependence in one or more IADL.

\section{Factor analysis of FVI-DD for the definition of indicators}

The exploratory factor analysis defined seven factors, which accounted for $40.4 \%$ of the total cumulative variance. Of the 103 questions present in the original instrument, only 50 were maintained. The questions about child development-early work, access to education, educational development, and infant mortality-did not appear in the factor analysis. Other questions that were absent from the analysis were related to economic conditions, ability to generate income, property, sheltering, access to water supply, sanitation, garbage disposal, electricity, hospital admissions, physical disability, and mental health. Table 1 shows the distribution of questions for each factor and the respective values of the factor correlation matrix with orthogonal varimax rotation.

In factor 1, the questions were related to better living conditions and therefore were designated favorable social conditions. Affirmative responses indicated less vulnerability and were assigned a score of 0 , whereas negative responses represented greater vulnerability and were assigned a score of 1 .

In factor 2, designated aging, the questions dealt with the aging process and its association with family access to labor. Three questions that had already been covered in factor 1 were excluded. In questions $7,8,9,10,87$, and 91 , the affirmative responses indicated greater vulnerability and were assigned a score of 1 , whereas the negative responses indicated less vulnerability and were assigned a score of 0 . In questions 25,26 , and 27 , the assignment of scores was identical to that of factor 1 .

Factor 3 was designated chronic diseases and included questions related to chronic diseases. The affirmative responses indicated greater vulnerability and were assigned a score of 1 , whereas the negative responses indicated less vulnerability and were assigned a score of 0 .
Development and validation of the Family Vulnerability Index to Disability and Dependence Amendola F, Alvarenga MRM, Latorre MRDO, Oliveira MAC 
Factor 4 was designated unfavorable social conditions and referred to the presence of children or teenagers in the family and a family income below the poverty line. In addition, the relation between the number of bedrooms and the number of residents in each household needed to be greater than 2 . The question about the presence of elderly in the family was excluded because it had already been covered in factor 2 . The affirmative and negative responses had scoring assignments identical to those of factor 3 .

Factor 5 was designated social support and included questions related to social support. In this factor, the affirmative and negative responses had scoring assignments identical to those of factors 3 and 4 .

Factor 6 was designated illiteracy and included questions related to illiteracy of family members, particularly among family heads19. The question about the presence of family members with a College or University degree was withdrawn because it had already been covered in factor 1 . The scoring assignment for this factor was identical to that of factors 3 through 5 .

In factor 7, designated social networks, the questions involved social relations. The affirmative responses indicated less vulnerability and were assigned a score of 1 , whereas the negative responses indicated greater vulnerability and were assigned a score of 0 . The FVI-DD scores varied from zero to a maximum of 50 points. The higher the score, the greater the vulnerability to disability and dependence. We would like to emphasize that questions $17,18,19,22,23,24,25,26,27,30,59,60,61$, and 62 , were inversely scored, i.e., the affirmative responses indicated less vulnerability and were assigned a score of 0 , whereas the negative responses indicated greater vulnerability and were assigned a score of 1 .

Table 1 - Questions and description of factors of FVI-DD - São Paulo, 2011

\begin{tabular}{|c|c|c|c|}
\hline Factors & $\begin{array}{l}\text { Number of } \\
\text { questions }\end{array}$ & Question & $\mathbf{r}^{*}$ \\
\hline \multirow{10}{*}{ 1. Favorable social conditions } & \multirow{10}{*}{11} & 17. Has at least one adult completed school up to ninth grade? & 0.573 \\
\hline & & 18. Has anyone completed high school? & 0.685 \\
\hline & & 19. Does anyone have higher education? & 0.692 \\
\hline & & 22. Has the head of the household completed school up to ninth grade? & 0.55 \\
\hline & & 23 Has the head of the household completed high school? & 0.581 \\
\hline & & 30. Is anyone employed and earning more than two minimum wages? & 0.55 \\
\hline & & 59. Is there a landline phone in the house? & 0.42 \\
\hline & & 60. Is there a computer in the house? & 0.762 \\
\hline & & 61. Is there a computer with Internet access? & 0.722 \\
\hline & & 62. Does anyone own a motorcycle or a car for private use? & 0.5 \\
\hline \multirow{9}{*}{ 2. Aging } & \multirow{9}{*}{9} & 7. Is an elderly person living in the house (aged 60 or more)? & 0.495 \\
\hline & & 8. Is there an elderly person aged 80 or more? & 0.502 \\
\hline & & $\begin{array}{l}\text { 9. If there is only one person living in the house, is he/she an elderly person (aged } 60 \text { or } \\
\text { more)? }\end{array}$ & 0.567 \\
\hline & & 10. Are there only elderly people living in the house (aged 60 or more)? & 0.629 \\
\hline & & $\begin{array}{l}\text { 25. Do over half the people of working age engage in paid work? } \\
\text { *In this case, consider only members of } 16 \text { years or above (exclude child labor) }\end{array}$ & 0.52 \\
\hline & & 26. Has anyone been performing their current job for over six months? & 0.642 \\
\hline & & 27. Is anyone working in official employment (with a signed contract)? & 0.508 \\
\hline & & 87. Has any elderly person suffered a fall within the last 12 months? & 0.446 \\
\hline & & 91. Is anyone unable to take public transportation to their health-care center? & 0.439 \\
\hline \multirow{8}{*}{ 3. Chronic disease } & \multirow{8}{*}{9} & 78. Is anyone in the family suffering from at least one chronic disease? & 0.604 \\
\hline & & 79. Is anyone in the family suffering from at least two chronic diseases? & 0.643 \\
\hline & & 80. Is anyone in the family suffering from three or more chronic diseases? & 0.512 \\
\hline & & $\begin{array}{l}\text { 81. Is anyone suffering from a chronic disease and having difficulty in following their } \\
\text { drug treatment owing to personal reasons or lack of access to medicine? }\end{array}$ & 0.427 \\
\hline & & 83. Is anyone continuously using prescription drugs? & 0.6 \\
\hline & & $\begin{array}{l}\text { 84. Is anyone continuously using five or more prescription drugs at the same time (mul- } \\
\text { tidrugs)? }\end{array}$ & 0.594 \\
\hline & & 88. Does anyone believe that his/her health is poor or very poor? & 0.525 \\
\hline & & $\begin{array}{l}\text { 99. Is anyone unable to perform any of the following activities without assistance: } \\
\text { cleaning the house, taking care of laundry, preparing food, using household appliances, } \\
\text { shopping, using personal or public transportation, and controlling their own medication } \\
\text { or finances? (instrumental activities of daily living - IADL) }\end{array}$ & 0.437 \\
\hline
\end{tabular}




\begin{tabular}{|c|c|c|c|}
\hline Factors & $\begin{array}{l}\text { Number of } \\
\text { questions }\end{array}$ & Question & $\mathbf{r}^{*}$ \\
\hline \multirow{5}{*}{ 4. Unfavorable social conditions } & \multirow{5}{*}{5} & 2. Has any woman given birth to a living child in the last 24 months? & 0.513 \\
\hline & & 5. Is there any child or adolescent up to the age of 14 in the house? & 0.858 \\
\hline & & 6. Is there any child or adolescent up to the age of 17 in the house? & 0.838 \\
\hline & & 32. Is the family income between a quarter and a half of the minimum wage per person? & 0.451 \\
\hline & & 46. Is the total number of residents divided by the number of bedrooms greater than two? & 0.596 \\
\hline \multirow{6}{*}{ 5. Social support } & \multirow{6}{*}{6} & $\begin{array}{l}\text { 72. Does anyone not have someone they can count on if they need assistance in perform- } \\
\text { ing their domestic duties such as preparing food and cleaning the house? }\end{array}$ & 0.742 \\
\hline & & $\begin{array}{l}\text { 73. Does anyone not have someone they can count on if they need assistance for material } \\
\text { goods? }\end{array}$ & 0.684 \\
\hline & & 74. Does anyone not have someone they can count on if they need financial assistance? & 0.696 \\
\hline & & 75. Does anyone not have someone they can count on if they need company? & 0.758 \\
\hline & & 76. Does anyone not have someone they can count on if they need health assistance? & 0.821 \\
\hline & & $\begin{array}{l}\text { 77. Does anyone not have someone they can count on to accompany them when they } \\
\text { need to leave the house (for medical consultations, shopping, walks, etc.)? }\end{array}$ & 0.752 \\
\hline \multirow{3}{*}{ 6. Illiteracy } & \multirow{3}{*}{3} & $\begin{array}{l}\text { 15. Is there an illiterate adult in the household or someone who can only read and write } \\
\text { their own name? }\end{array}$ & 0.763 \\
\hline & & 16. Is there an adult with reading and writing difficulties (functional illiteracy)? & 0.695 \\
\hline & & $\begin{array}{l}\text { 20. Is the head of the household illiterate or only capable of reading and writing his own } \\
\text { name? }\end{array}$ & 0.712 \\
\hline \multirow{7}{*}{ 7. Social network } & \multirow{7}{*}{7} & $\begin{array}{l}\text { 64. Are there friends who live nearby (within walking distance) and who maintain } \\
\text { contact? }\end{array}$ & 0.606 \\
\hline & & 66. Do family members visit at least once a week? & 0.513 \\
\hline & & 67. Do family members visit at least once a month? & 0.55 \\
\hline & & 68. Do family members visit at least once a year? & 0.403 \\
\hline & & 69. Do friends visit at least once a week? & 0.568 \\
\hline & & 70. Do friends visit at least once a month? & 0.737 \\
\hline & & 71. Do friends visit at least once a year? & 0.626 \\
\hline Total & 50 & & - \\
\hline
\end{tabular}

Table 2 shows the high internal consistency of each factor $(\alpha \geq 0.73)$. Similarly, the internal consistency of the sum of all the factors (total FVI-DD) was considered satis- factory $(\alpha=0.82)$. The total FVI-DD ranged from 1 to 31 points, with a mean \pm standard deviation of $15.46 \pm 6.60$ and a median of 15.00 .

Table 2 - Descriptive statistic of FVI-DD - São Paulo, 2011.

\begin{tabular}{|c|c|c|c|c|}
\hline Factors & Cronbach's alpha & Mean (SD) & Median & Min-max \\
\hline 1. Favaroble social conditions & 0.86 & $5.31(3.30)$ & 5 & $0-11$ \\
\hline 2. Aging & 0.81 & $2.33(2.32)$ & 1 & $0-9$ \\
\hline 3. Chronic diseases & 0.78 & $3.19(2.31)$ & 3 & $0-9$ \\
\hline 4. Unfavorable social conditions & 0.78 & $1.08(1.41)$ & 0 & $0-5$ \\
\hline 5. Social support & 0.85 & $1.06(1.72)$ & 0 & $0-6$ \\
\hline 6. Illiteracy & 0.77 & $0.34(0.78)$ & 0 & $0-3$ \\
\hline 7. Social network & 0.73 & $2.14(1.83)$ & 2 & $0-7$ \\
\hline FVI-DD Total & 0.82 & $15.46(6.60)$ & 15 & $1-31$ \\
\hline
\end{tabular}

The total FVI-DD and the factors aging and chronic diseases enabled the discrimination of households with and without dependence in BADL, according to the Katz Index. The mean values for these factors were consistently higher in households that had people with dependence $(p<0.05)$. With regard to IADL (Lawton scale), we observed that the total FVI-DD and the factors age chronic diseases, unfavorable social conditions, and social support were able to discriminate household members with dependence, and higher mean values were found for the latter three factors $(p<0.05)$, as observed in Table 3. 
Table 3 - Descriptive statistics of indicators of FVI-DD, depending on the presence of dependence on basic activities of daily living (BADL) of the Katz Index and on the instrumental activities of the Lawton Scale - São Paulo, 2011.

\begin{tabular}{|c|c|c|c|c|c|c|}
\hline \multirow[t]{2}{*}{ Components } & \multirow{2}{*}{$\begin{array}{l}\text { Presence of } \\
\text { dependency }\end{array}$} & \multirow{2}{*}{$\begin{array}{c}\text { No one in the family } \\
\text { with dependency }\end{array}$} & \multicolumn{3}{|c|}{$\begin{array}{l}\text { At least one person in the family } \\
\text { with BADL or IADL dependency }\end{array}$} & \multirow[t]{2}{*}{ p\# } \\
\hline & & & (SD) & Mean & (SD) & \\
\hline \multirow{2}{*}{ 1. Favorable social conditions } & KATZ & 5.27 & -3.25 & 5.7 & -3.76 & 0.59 \\
\hline & LAWTON & 5.12 & -3.28 & 5.96 & -3.31 & 0.09 \\
\hline \multirow{2}{*}{ 2. Aging } & KATZ & 2.12 & -2.22 & 4.48 & -2.29 & $<0.001 *$ \\
\hline & LAWTON & 1.7 & -1.88 & 4.55 & -2.39 & $<0.001 *$ \\
\hline \multirow{2}{*}{ 3. Chronic disease } & KATZ & 3 & -2.26 & 5.3 & -1.66 & $<0.001^{*}$ \\
\hline & LAWTON & 2.55 & -2.09 & 5.44 & -1.51 & $<0.001 *$ \\
\hline \multirow{2}{*}{ 4. Unfavorable social conditions } & KATZ & 1.13 & -1.43 & 0.65 & -1.11 & 0.14 \\
\hline & LAWTON & 1.27 & -1.47 & 0.42 & -0.92 & $<0.001^{*}$ \\
\hline \multirow{2}{*}{ 5. Social support } & KATZ & 1.1 & -1.74 & 0.61 & -1.5 & 0.06 \\
\hline & LAWTON & 1.07 & -1.73 & 1.02 & -1.71 & 0.99 \\
\hline \multirow{2}{*}{ 6. Illiteracy } & KATZ & 0.31 & -0.73 & 0.65 & -1.15 & 0.15 \\
\hline & LAWTON & 0.29 & -0.74 & 0.53 & -0.9 & $0.01 *$ \\
\hline \multirow{2}{*}{ 7. Social network } & KATZ & 2.11 & -1.81 & 2.43 & -2.04 & 0.49 \\
\hline & LAWTON & 2.12 & -1.77 & 2.22 & -2.04 & 0.97 \\
\hline \multirow{2}{*}{ FVI-DD Total } & KATZ & 15.01 & -6.55 & 19.83 & -5.47 & $<0.01 *$ \\
\hline & LAWTON & 14.13 & -6.27 & 20.13 & -5.55 & $<0.01 *$ \\
\hline
\end{tabular}

\# Mann-Whitney test

* statistically significant difference $(p<0.05)$

The total FVI-DD had a significant correlation for the two instruments (concurrent validity), indicating that the higher the score, the greater the vulnerability $(r=0.23$, $p<0.01$ ) using the Katz Index (greater dependence). In addition, the higher the factor score, the lower the score on the Lawton scale $(r=-0.39, p<0.01$; greater dependence). The components aging and chronic conditions also exhibited a significant correlation using both instruments (Table 4).
These results indicate that the higher the total FVI-DD score, the worse the family condition. Moreover, the definition of a cutoff value enabled the classification of families in terms of dependence. To define the cutoff value, a ROC curve was used, which was constructed on the basis of the Lawton scale. The area of the ROC curve was $0.769(p<0.01)$. The cutoff value of 15 had a sensitivity of 0.80 and a specificity of 0.54 . Therefore, families were considered vulnerable to disability and dependence at scores of $\geq 15$ in FVI-DD.

Table 4 - Spearman correlation coefficients (rsp) between the indicators of FVI-DD and Katz and Lawton mean family scores - São Paulo, 2011.

\begin{tabular}{lcc}
\hline \multicolumn{1}{c}{ Components } & Mean Katz score & Mean Lawton score \\
& $\operatorname{rsp}(\mathrm{p})$ & rsp $(\mathrm{p})$ \\
\hline 1. Favorable social conditions & $0.04(0.49)$ & $-0.12(0.06)$ \\
2. Aging & $0.30(<0.001)^{*}$ & $-0.50(<0.001)^{*}$ \\
3. Chronic diseases & $0.29(<0.001)^{*}$ & $-0.51(<0.001)^{*}$ \\
4. Unfavorable social conditions & $-0.10(0.12)$ & $0.27(<0.001)^{*}$ \\
5. Social support & $-0.12(0.06)$ & $0.02(0.78)$ \\
6. Illiteracy & $0.09(0.15)$ & $-0.17(0.01)^{*}$ \\
7. Social network & $0.05(0.48)$ & $-0.02(0.71)$ \\
FVI-DD Total & $0.23(<0.001)^{*}$ & $-0.40(<0.001)^{*}$ \\
\hline * statistically significant correlation $(\mathrm{p}<0.05)$ & &
\end{tabular}

${ }^{*}$ statistically significant correlation $(p<0.05)$

\section{DISCUSSION}

There was a predominance of women among household members interviewed in the Lapa neighborhood (54.6\%). Data on disability rates obtained from the National Survey for Household Sampling (NSHS) ${ }^{(13)}$ indicated a higher prevalence of functional disability among women, and this prevalence increased with age, reaching $16 \%$ for women aged $65-79$ years. With regard to age distribution, the percentage of elderly people in the sample was the highest in the city $(22.8 \%)$, and similar to that found in the Midwest region ${ }^{(8)}$.

In the households visited, the average number of residents was 3.2, similar to that found in the metropolitan region of Sao Paulo (3.2) and in Brazil (3.3) (14). However, $9.7 \%$ of the surveyed population lived alone. Accordingly, 
the population census in Brazil reported that $6,980,378$ people lived alone in 2010, which represented $12.2 \%$ of the permanent private households in the country ${ }^{(14)}$. Moreover, $9.3 \%$ of the families had at least one person with partial or total dependence in BADL and $22.2 \%$ in IADL, which is significant and relevant data when contemplating the provision of health care by primary care professionals.

The instrument under study initially consisted of 103 questions, classified into eight dimensions. After exploratory factor analysis, 50 questions were maintained. Among the factors in the dimensions health conditions and social relations from the original index, the only factors that were not included in the analysis were admissions and mental health. However, previous studies have shown that hospital admissions were related to both dependence ${ }^{(5)}$ and mortality ${ }^{(15)}$ for the elderly. One explanation is that the instrument may not be specific to the elderly or to certain diagnoses and applies only for family assessment. In this case, important insight derived from studies with the elderly may not apply to the present instrument.

The first factor analyzed included questions related to good living conditions. In this respect, previous studies have indicated a positive correlation of poor schooling and low income with a higher degree of disability ${ }^{(13,16-17)}$. However, other studies did not find such association ${ }^{(18-19)}$. Education and income level should not be viewed merely as potential risk factors for disability and dependence, but as family conditions that, if unfavorable, may limit the possibilities of adequate care, exposing families to vulnerable conditions.

Another factor covered questions related to health conditions, with an emphasis on employment and aging. NSHS data have indicated that the rate of employment among people over 40 years is rising, and in 2012, 7.2\% of the employed were aged $\geq 60$ years(20). Research data on health, welfare, and aging - Saúde, Bem Estar e Envelhecimento (SABE) - found that $59.7 \%$ of the elderly were still employed and salaries were the major source of income for this group, followed by tenancy and severance pay. This may explain the positive correlation between employment opportunities and aging ${ }^{(21)}$.

There is a consensus that disability is directly related to increasing age. Accordingly, several studies have investigated disability and dependence among seniors ${ }^{(4-5,18)}$. However, few studies have evaluated these conditions in the general population ${ }^{(7,22-23)}$; one of these studies has classified the Spanish population in situations of dependence and revealed the existence of an evolutionary profile of the degree of dependence in BADL after the age of $60^{(23)}$.

Polypharmacy and falling are strongly correlated with age and are highly prevalent among the elderly. Previous studies have indicated the relation of disability and dependence with polypharmacy ${ }^{(24)}$ and falling in the elderly ${ }^{(25)}$. In this sense, the question about access to health services also aimed to assess the ability to travel using public transportation. Of note, the ability to move using any means of transportation was the most prevalent IADL $(17.6 \%)^{(19)}$.

The third factor comprised questions about the existence of chronic illnesses in the families. In this respect, several studies have found an association of disability and dependence with chronic diseases ${ }^{(5,18)}$, and this association was more frequent for brain vascular accidents and urinary incontinence ${ }^{(16,18)}$.

With respect to IADL, a previous study found that high blood pressure in the elderly increased the risk for various conditions, including dependence risk by $39 \%$, heart disease by $82 \%$, arthropathy by $59 \%$, and pulmonary disease by $50 \%$. For dependence in both BADL and IADL, the risk more than doubled for each of these conditions ${ }^{(4)}$. Moreover, studies involving the elderly have given considerable importance to self-assessment of health in this group. Accordingly, several studies with the elderly indicated an association between negative self-assessment of health and the occurrence of disability and dependence ${ }^{(5,16-18)}$.

The presence of children and teenagers in the family can also lead to social vulnerabilities because families have additional expenses with these groups, who have specific education and health care needs ${ }^{(9)}$. In general, depending on the family cycle, families with small children and young people have fewer elderly and therefore would be less vulnerable to disability and dependence. In addition, the SABE ${ }^{(21)}$ study found that older people in more favorable conditions are those who live with a spouse and have no children, whereas the elderly who lived with married children (and most likely shared housing with grandchildren) experienced the least favorable conditions.

Factor 5 contained questions about social support. In Sao Paulo, the number of seniors who reported having three or more diseases or difficulty in performing BADL was significantly higher among those who lived with married children. In fact, these elderly received less support for $B A D L$, indicating the importance of the family as the primary source of support for older people with disability and dependence $^{(21)}$.

Factor 6 comprised indicators of illiteracy in the families, particularly for the head of the family. These indicators do not always correlate with disability and dependence $^{(18-19)}$; however, they may indicate conditions that create an unfavorable scenario for families who care for such people.

The seventh and last component contemplated the questions concerning the frequency of visits from family and friends. A previous study found no association between visiting friends and moderate or severe dependence ${ }^{(5)}$, whereas another study found a negative association between the number of friends visiting in the last 30 days and severe disability ${ }^{(18)}$.
Development and validation of the Family Vulnerability Index to Disability and Dependence Amendola F, Alvarenga MRM, Latorre MRDO, Oliveira MAC 


\section{CONCLUSIONS}

This study indicated the steps for the development of FVI-DD, which is a comprehensive index with a defined structure, created to identify family vulnerability to disability and dependence. The instrument was validated in 248 families served by the Family Health Strategy (FHS) and its performance was tested using widely used scales, such as the Katz Index and the Lawton scale.

\section{REFERENCES}

1. Brasil. Ministério da Saúde. Portaria n. 2.029, de 24 de agosto de 2011. Institui a Atenção Domiciliar no âmbito do Sistema Único de Saúde [Internet]. Brasília; 2011 [citado 2011 out. 29]. Disponível em: http://bvsms.saude.gov.br/ bvs/saudelegis/gm../2011/prt2029_24_08_2011.html

2. Querejeta González M. Discapacidad/dependencia: unificación de critérios de valoración y clasificación [Internet]. Madrid: IMSERSO; 2004 [citado 2010 mar 03]. La discapacidad. p. 9-17. Disponíbel en: http://www.index-f.com/lascasas/documentos/Ic0181.pdf

3. Ayres JRCM, França Júnior I, Calazans GJ, Saletti Filho HC. O conceito de vulnerabilidade e as práticas de saúde: novas perspectivas e desafios. In: Czeresnia D, Freitas CM, organizadores. Promoção da saúde: conceitos, reflexões, tendências. Rio de Janeiro: FIOCRUZ; 2003. p. 117-39.

4. Alves LC, Leimann BCQ, Vasconcelos MEL, Carvalho MS, Vasconcelos AGG, Fonseca TCO, et al. A influência das doenças crônicas na capacidade funcional dos idosos do Município de São Paulo, Brasil. Cad Saúde Pública [Internet]. 2007 [citado 2011 jan. 20]; 23 (8):1924-30. Disponível em: http:// www.scielo.br/pdf/csp/v23n8/19.pdf

5. Rosa TEC, Benicio MHD'A, Latorre MRDO, Ramos LR. Fatores determinantes da capacidade funcional entre idosos. Rev Saúde Pública [Internet]. 2003 [citado 2011 jan. 20]; 37(1): 40-8. Disponível em: http://www.scielosp.org/pdf/rsp/ v37n1/13543.pdf

6. Lima-Costa M, Matos DL, Camarano AA. Evolução das desigualdades sociais em saúde entre idosos e adultos brasileiros: um estudo baseado na Pesquisa Nacional por Amostra de Domicílios (PNAD 1998, 2003). Ciênc Saúde Coletiva [Internet]. 2006 [citado 2010 jun. 12];11(4):941-50. Disponível em: http://www.scielo.br/pdf/csc/v11n4/32331. pdf

7. Gaspar JC, Oliveira MAC, Duayer MFF. Perfil dos pacientes com perdas funcionais e dependência atendidos pelo PSF no município de São Paulo. Rev Esc Enferm USP 2007;41(4):619-28.
The results from this study may enable the application of this index to other populations. However, further empirical studies are warranted to confirm its psychometric properties.

We believe that FVI-DD will be a useful tool for professionals working with FHS not only by enabling the monitoring family vulnerabilities but also by supporting the planning of activities for prevention, monitoring, and intervention of the health care network to prevent further vulnerability to disability and dependence.

8. São Paulo (Cidade). Secretaria Municipal de Saúde; Coordenação de Epidemiologia e Informação (CEInfo). Indicadores para diagnóstico de saúde da cidade de São Paulo. [Internet]. São Paulo; 2011 [citado 2011 ago. 20]. Disponível em: http://www.prefeitura.sp.gov.br/cidade/secretarias/upload/saude/arquivos/publicacoes/DiagnosticoSinteticoSaudeCidSaoPaulo_CEInfo_18jan11.pdf

9. Carvalho $M$, Barros RP, Franco S. Índice de desenvolvimento da família. In: Acosta AR, Vitale MAF, organizadores. Família: redes, laços e políticas. São Paulo: Instituto de Estudos Especiais, Pontifícia Universidade Católica de São Paulo; 2003. p. 241-65.

10. Amendola F, Alvarenga MRM, GJC, Yamashita $\mathrm{CH}$, Oliveira MAC. Face validity of an index of family vulnerability to disability and dependence. Rev Esc Enferm USP [Internet]. 2011 [cited 2013 Oct 14];45(n.spe 2):1736-42. Available from: http://www.scielo.br/pdf/reeusp/v45nspe2/en_17. pdf

11. Katz S, Ford AB, Moskowitz RW, Jackson BA, Jaffe MW. Studies of illness in the aged. The index of ADL: a standardized measure of biological and psychosocial function. JAMA. 1963;185(12):914-9.

12. Brasil. Ministério da Saúde; Secretaria de Atenção à Saúde, Departamento de Atenção Básica. Envelhecimento e saúde da pessoa idosa. Brasília; 2006. (Cadernos de Atenção Básica, 19).

13. Parahyba MI, Veras R, Melzer D. Incapacidade funcional entre as mulheres idosas no Brasil. Rev Saúde Pública. 2005;39(3):383-91.

14. Instituto Brasileiro de Geografia e Estatística (IBGE). Indicadores Sociais Municipais: uma análise dos resultados do universo do Censo Demográfico 2010 [Internet]. Rio de Janeiro; 2011 [citado 2013 out. 14]. Disponível em: http://www.ibge. gov.br/home/estatistica/populacao/censo2010/indicadores_sociais_municipais/indicadores_sociais_municipais.pdf 
15. Ramos LR, Simões E, Albert MS. Dependency on daily living and cognitive impairment strongly predicted mortality among urban elderly residents in Brazil: a two-year followup. J Am Geriatr Soc. 2001;49(9):1168-75.

16. Giacomin KC, Uchôa E, Firmo JOA, Lima-Costa MF. Projeto Bambuí: um estudo de base populacional da prevalência e dos fatores associados à necessidade de cuidador entre idosos. Cad Saúde Pública. 2005;21(1):80-91.

17. Santos KA, Koszuoski R, Dias-da-Costa JS, Pattussi MP. Fatores associados com a incapacidade funcional em idosos do Município de Guatambu, Santa Catarina, Brasil. Cad Saúde Pública. 2007;23(11):2781-8.

18. Giacomin KC, Peixoto SV, Uchoa E, Lima-Costa MF. Estudo de base populacional dos fatores associados à incapacidade funcional entre idosos na Região Metropolitana de Belo Horizonte, Minas Gerais, Brasil. Cad Saúde Pública [Internet]. 2008 [citado 2011 abr. 09]; 24(6):1260-70. Disponível em: http://www.scielo.br/pdf/csp/v24n6/07.pdf

19. Del Duca GF, Silva MC, Hallal PC. Incapacidade funcional para atividades básicas e instrumentais da vida diária em idosos. Rev Saúde Pública. 2009;43(5):796-805.

20. Instituto Brasileiro de Geografia e Estatística (IBGE). Pesquisa Nacional por Amostra de Domicílios (PNAD). Síntese de indicadores 2012 [Internet]. Rio de Janeiro; 2012. [citado 2012 nov. 13]. Disponível em: ftp://ftp.ibge.gov. br/Trabalho_e_Rendimento/Pesquisa_Nacional_por_ Amostra_de_Domicilios_anual/2012/Sintese_Indicadores/ comentarios2012.pdf
21. Saad PM. Arranjos domiciliares e transferências de apoio informal. In: Lebrão ML, Duarte YAO, organizadoras. SABE Saúde, Bem-Estar e Envelhecimento. O Projeto SABE no município de São Paulo: uma abordagem inicial. Brasília: OPAS; 2003. p. 203-24.

22. Magarolas RG, Clot-Razquin G, Fernandéz AR, Ramírez AF, Ruíz-Ramos $M$, Luque $C R$, et al. El perfil de la dependencia en España: un análisis de la encuesta de discapacidades de 1999. Rev Esp Salud Pública. 2008;82(6):653-65.

23. Albarrán Lozano I, Alonso Gonzáles P. Clasificación de las personas dependientes a partir de la encuesta de discapacidades, deficiências y estado de salud de 1999. Rev Esp Salud Pública. 2006;80(4):349-60.

24. Cunha FCM, Cintra MTG, Cunha LCM, Couto EAB, Giacomin $\mathrm{KC}$. Fatores que predispõem ao declínio funcional em idosos hospitalizados. Rev Bras Geriatr Gerontol. 2009;12(3):475-87.

25. Perracini MR, Ramos LR. Fatores associados a quedas em uma coorte de idosos residentes na comunidade. Rev Saúde Pública. 2002;36(6):709-16.

\section{Acknowledgements}

This research was funded by Sao Paulo Research Foundation (FAPESP), process N. 2010/20568-3 